\title{
Reciprocal Production of Adiponectin and C-reactive Protein in Coronary Circulation of Patients with and without Coronary Artery Disease
}

Authors

Affiliation
J. Kawagoe, T. Imamura, H. Date, T. Ideguchi, S. Koyama, Y. Nagoshi, M. Tatsumoto, H. Onitsuka, H. Iwakiri, K. Kitamura

First Department of Internal Medicine, Faculty of Medicine, University of Miyazaki, Kiyotake Miyazaki, Japan received 27.08.2007

accepted 21.01.2008

Bibliography

DOI $10.1055 / \mathrm{s}-2008-1073150$

Published online:

May 5, 2008

Horm Metab Res 2008;

40: $578-580$

(c) Georg Thieme Verlag KG

Stuttgart · New York

ISSN 0018-5043

Correspondence

T. Imamura, MD

First Department of Internal

Medicine

Faculty of Medicine

University of Miyazaki

Kihara 5200

Kiyotake

Miyazaki 889-1692

Japan

Tel.: + 81/985/85 0872

Fax: +81/985/85 6596

imatak@med.miyazaki-u.ac.jp

\section{Introduction}

$\nabla$

The adipocyte-specific plasma protein adiponectin was originally isolated from human adipose tissues. Adiponectin has anti-atherosclerotic properties such as the suppression of adhesion molecule expression on endothelial cells, the proliferation of vascular smooth muscle cells, and the transformation of macrophages to foam cells. Systemic clinical hypoadiponectinemia is closely associated with obesity, type 2 diabetes, and coronary artery disease (CAD) [1]. These data suggest that adiponectin contributes to suppressing the initiation and progression of atherosclerosis. We already reported that adiponectin is locally produced in the coronary circulation and might participate in modulating the coronary circulation [2]. Iacobellis et al. recently showed that epicardial adipose tissue expresses adiponectin protein and that the level is significantly lower in patients with, than in those without, CAD [3]. Locally produced adiponectin might exert local anti-atherosclerotic action on the adjacent coronary artery [3]. These findings together indicate that the locally produced adiponectin in the coronary circulation might be at least partly attributable to its production and secretion from epicardial adipose tissue and affect coronary atherosclerosis. However, whether the plasma level of adiponectin in the coronary circulation varies with the presence of CAD remains unknown. We therefore investigated the relationship between the presence of CAD and the amount of adiponectin production in the coronary circulation and compared with the amount of C-reactive protein (CRP) in the coronary circulation of patients with and without CAD.

\section{Materials and Methods \\ $\nabla$}

We examined 26 consecutive patients ( 17 men and 9 women; mean age $66 \pm 2.0$ years) whose left anterior descending coronary arteries required coronary intervention because of severe stenosis ( $>75 \%$ diameter stenosis) associated with stress-induced ischemia and 24 consecutive patients (11 men and 13 women; mean age $62.0 \pm 2.0$ years) without CAD. Patients without CAD were diagnosed as having atypical chest pain and angiographically normal coronary arteries. Patients who had myocardial infarction were excluded from this study. Plasma levels of adiponectin and CRP were measured in blood samples that were simultaneously collected from the orifice of the left coronary artery and the great cardiac vein, which selectively drains blood from the left anterior descending coronary artery, after control coronary angiography. The lower range of plasma adiponectin levels measured using ELISA kits was $1.9 \mu \mathrm{g} / \mathrm{ml}$ and that of CRP using the Dade Behring BN II N high-sensitivity CRP assay was $0.175 \mathrm{mg} / \mathrm{l}$. Written, informed consent was obtained from all patients to participate in the study, and the Ethics Committee of our institution approved the study protocol. The positive value of the plasma adiponectin or CRP level in the great cardiac vein minus that in the coronary artery (transcoronary difference) suggested the amount of adiponectin or CRP production in the coronary circulation. We compared the amount of adiponectin and CRP production throughout the coronary circulation between patients with and without CAD. The distribution of plasma adiponectin and CRP levels was skewed, and thus comparisons were made using a nonparametric analysis. The Wilcoxon rank sum test was used for the comparison between the coronary artery and great cardiac vein, and the Mann-Whitney test was used for the comparison between patients with and without CAD. A value of $\mathrm{p}<0.05$ was considered statistically significant. 


\section{Results}

$\nabla$

Baseline characteristics of the participants (Table 1) did not significantly differ except for aspirin therapy. Plasma adiponectin levels in the great cardiac vein were significantly higher than those in the coronary artery of patients both with (median $5.25 \mu \mathrm{g} / \mathrm{ml}$ vs. $5.05 \mu \mathrm{g} / \mathrm{ml}, \mathrm{p}<0.005$ ) and without (median, $7.35 \mu \mathrm{g} / \mathrm{ml}$ vs. $6.95 \mu \mathrm{g} / \mathrm{ml}, \mathrm{p}<0.001$ ) CAD. Plasma adiponectin levels in the coronary artery of patients with CAD were significantly lower than in that of patients without CAD (median, $5.05 \mu \mathrm{g} / \mathrm{ml}$ vs. $6.95 \mu \mathrm{g} / \mathrm{ml}, \mathrm{p}<0.05)$. The transcoronary difference in plasma adiponectin levels ( $\Delta$ adiponectin) was significantly lower in patients with than in those without CAD (median, $0.30 \mu \mathrm{g} / \mathrm{ml}$ vs. $0.45 \mu \mathrm{g} / \mathrm{ml}, \mathrm{p}<0.05$; ○ Fig. 1A). Likewise, plasma CRP levels in the great cardiac vein were significantly higher than those in the coronary artery of patients with (median $1.370 \mathrm{mg} / \mathrm{l}$ vs. $1.265 \mathrm{mg} / \mathrm{l}, \mathrm{p}<0.001$ ) and without (median,

Table 1 Baseline clinical characteristics of the study population

\begin{tabular}{|c|c|c|c|}
\hline Variable & $\begin{array}{l}\text { With CAD } \\
(n=26)\end{array}$ & $\begin{array}{l}\text { Without } \\
\text { CAD }(n=24)\end{array}$ & P-value \\
\hline age & $66 \pm 2.0$ & $62 \pm 2.0$ & n.s. \\
\hline male/female & $17 / 9$ & $11 / 13$ & n.s. \\
\hline body mass index $\left(\mathrm{kg} / \mathrm{m}^{2}\right)$ & $24.4 \pm 0.76$ & $23.8 \pm 0.86$ & n.s. \\
\hline smoker (\%) & $6(23)$ & $3(13)$ & n.s. \\
\hline $\begin{array}{l}\text { family history of ischemic } \\
\text { heart disease (\%) }\end{array}$ & $5(19)$ & $3(13)$ & n.s. \\
\hline $\begin{array}{l}\text { systolic blood pressure } \\
(\mathrm{mmHg})\end{array}$ & $135.3 \pm 3.2$ & $132.2 \pm 3.2$ & n.s. \\
\hline $\begin{array}{l}\text { diastolic blood pressure } \\
(\mathrm{mmHg})\end{array}$ & $77.6 \pm 2.1$ & $75.0 \pm 1.7$ & n.s. \\
\hline total cholesterol (mg/dl) & $188.4 \pm 7.0$ & $204.0 \pm 4.7$ & n.s. \\
\hline triglyceride (mg/dl) & $119.8 \pm 14.1$ & $132.9 \pm 27.7$ & n.s. \\
\hline diabetes mellitus (\%) & $10(38)$ & $3(13)$ & n.s. \\
\hline $\begin{array}{l}\text { fasting plasma glucose } \\
(\mathrm{mg} / \mathrm{dl})\end{array}$ & $104.3 \pm 2.9$ & $95.9 \pm 3.2$ & n.s. \\
\hline $\begin{array}{l}\text { angiotensin II receptor } \\
\text { blockers (\%) }\end{array}$ & $10(38)$ & $6(25)$ & n.s. \\
\hline calcium channel blockers (\%) & $5(19)$ & $5(21)$ & n.s. \\
\hline$\beta$-blockers (\%) & $4(15)$ & $5(21)$ & n.s. \\
\hline statins (\%) & $8(31)$ & $3(13)$ & n.s. \\
\hline aspirin (\%) & $15(58)$ & $4(17)$ & $\mathrm{p}<0.01$ \\
\hline$\alpha$-glucosidase inhibitors (\%) & $2(8)$ & $1(4)$ & n.s. \\
\hline sulfonylurea agents (\%) & $6(23)$ & $1(4)$ & n.s. \\
\hline
\end{tabular}

$0.422 \mathrm{mg} / \mathrm{l}$ vs. $0.364 \mathrm{mg} / \mathrm{l}, \mathrm{p}<0.05)$ CAD. In contrast, the transcoronary difference in plasma CRP levels ( $\triangle \mathrm{CRP}$ ) was significantly higher in patients with than in those without CAD (median, $0.110 \mathrm{mg} / \mathrm{l}$ vs. $0.013 \mathrm{mg} / \mathrm{l}, \mathrm{p}<0.01$; \& Fig. 1B).

\section{Discussion}

$\nabla$

The present study showed that adiponectin is produced in lesser quantities in the coronary circulation of patients with CAD than in those without CAD. In contrast, CRP is produced in greater quantities in the coronary circulation of patients with CAD than in those without CAD.

The production site of adiponectin in the coronary circulation is thought to be epicardial adipose tissue or adipose tissue in the myocardium, because the mRNA of adiponectin was originally detected solely in adipose tissue. Iacobellis et al. recently showed that epicardial adipose tissue expresses significantly less adiponectin protein in patients with severe CAD than in those without CAD [3]. However, whether the plasma level of adiponectin in the coronary circulation differs between patients with CAD and those without CAD remained obscure. We observed herein that plasma adiponectin levels are in fact lower in the coronary circulation of patients with CAD versus those without CAD. Circulating adiponectin levels are much higher in women than in men. Although the transcoronary difference in adiponectin levels was lower in patients with CAD than in those without CAD for both men and women, the difference was not significant because of the small sample size. Epicardial adipose tissue is also a source of inflammatory factors such as interleukin- $1 \beta$, interleukin- 6 , monocyte chemotactic protein- 1 , and tumor necrosis factor- $\alpha$ [4]. These findings suggest that epicardial adipose tissue is involved in a localized cytokine-inflammatory pathway in the coronary circulation. We reported that plasma CRP and interleukin-6 levels are increased in the coronary circulation of patients with CAD compared with those without CAD $[5,6]$. Additionally, Ouchi et al. reported that human adipose tissue expresses the CRP gene and the adiponectin gene and might partially account for elevated plasma CRP and adiponectin levels. These authors concluded that the reciprocal association of adiponectin and CRP levels in both plasma and adipose tissue might participate in the development of atherosclerosis [7]. Based on these findings, epicardial adipose
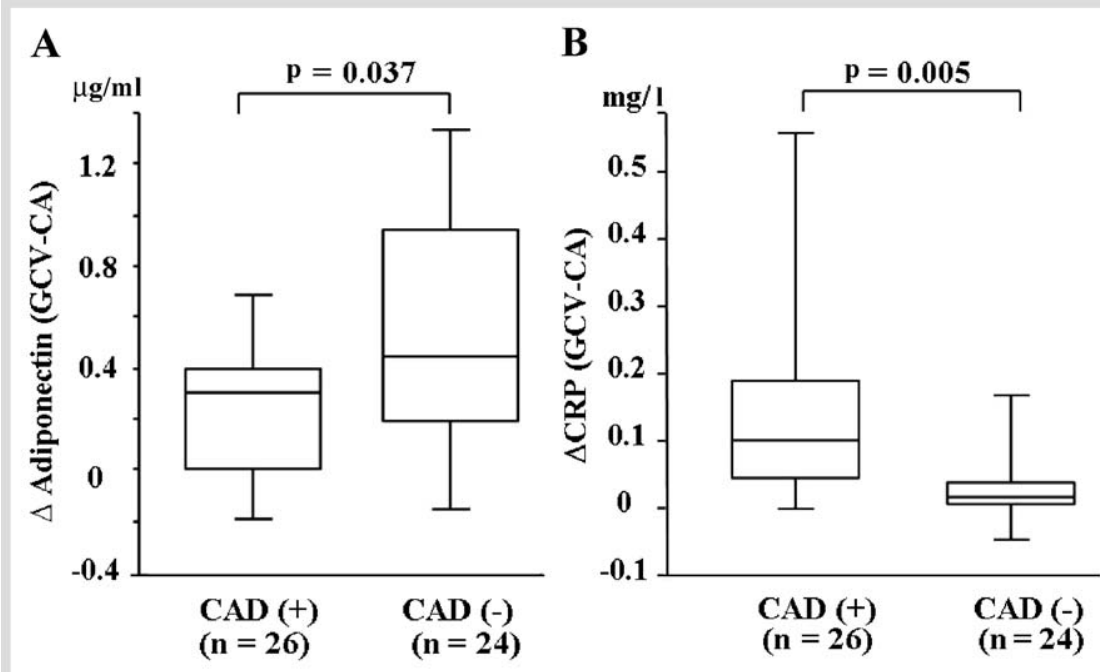

Fig. 1 Transcoronary difference in plasma adiponectin levels ( $\Delta$ adiponectin) $(\mathbf{A})$ and in plasma C-reactive protein (CRP) levels ( $\Delta$ CRP) (B). Transcoronary difference in adiponectin is defined as the plasma adiponectin level in the great cardiac vein (GCV) minus that in the coronary artery (CA). Horizontal bars represent 25th percentile, median, and 75 th percentile. 
tissue could contribute to the increase in adiponectin and CRP plasma levels in the coronary circulation and the involvement in the suppression and progression of coronary atherosclerosis. Epicardial fat is a metabolically active tissue that generates many bioactive molecules [8], and it may be an important factor in cardiovascular disease [9].

The adipocyte-specific plasma protein adiponectin is locally produced in the coronary circulation at lower levels in patients with CAD compared with those without CAD. Although the production site of adiponectin in the coronary circulation remains unknown, epicardial adipose tissue could be a candidate. Because a recent report shows the expression of adiponectin in cardiomyocytes, adiponectin produced in cardiomyocytes may affect its levels in the coronary circulation. However, adiponectin is produced mainly in the adipose tissue, and adipocytes are thought to be a more important production site of adiponectin than cardiomyocytes. In addition, patients with previous myocardial infarction were excluded from this study, and the left ventricular ejection fraction did not differ between the groups of patients with and without CAD. Furthermore, the transcoronary difference in adiponectin levels did not correlate with the left ventricular ejection fraction in this study. This background suggests that if the ventricular myocytes generate adiponectin, then the difference in adiponectin produced by the ventricular myocytes between the two groups can be ignored. Underlying diseases such as diabetes, hypertension, and hyperlipidemia and medications differed between the two groups of study participants. Because these conditions might diversely affect plasma levels of adiponectin [10], some caution might be needed in interpreting this result. In addition, the sample size of the present study was small, and further investigations are required to confirm that locally produced adiponectin contributes, at least in part, to suppressing the progression of coronary atherosclerosis in an autocrine or paracrine manner.

\section{References}

1 Fischer-Posovszky P, Wabitsch M, Hochberg Z. Horm Metab Res 2007; 39: 314-321

2 Date H, Imamura T, Ideguchi T, Kawagoe J, Sumi T, Masuyama H, Onitsuka H, Ishikawa T, Nagoshi T, Eto T. Clin Cardiol 2006; 29: 211-214

3 Iacobellis G, Pistilli D, Gucciardo M, Leonetti F, Miraldi F, Brancaccio G, Gallo P, Gioia CRT Di. Cytokine 2005; 29: 251-255

4 Mazurek T, Zhang L, Zalewski A, Mannion JD, Diehl JT, Arafat H, Sarov-Blat L, O'Brien S, Keiper EA, Johnson AG, Martin J, Goldstein BJ, Shi Y. Circulation 2003; 108: 2460-2466

5 Ishikawa T, Imamura T, Hatakeyama K, Date H, Nagoshi T, Kawamoto R, Matsuyama H, Asada Y, Eto T. Am J Cardiol 2004; 93: 611-614

6 Date H, Imamura T, Sumi T, Ishikawa T, Kawagoe J, Onitsuka H, Kawamoto R, Nagoshi T, Eto T. Am J Cardiol 2005; 95: 849-852

7 Ouchi $N$, Kihara $S$, Funahashi $T$, Nakamura $T$, Nishida $M$, Kumada M, Okamoto Y, Ohashi K, Nagaretani H, Kishida K, Nishizawa H, Maeda N, Kobayashi H, Hiraoka H, Matsuzawa Y. Circulation 2003; 107: 671-674

8 Iacobellis G, Corradi D, Sharma AM. Nature Clin Practice Cardiovasc Med 2005; 2: 536-543

9 Rabkin SW. Obesity Rev 2007; 8: 253-261

10 Helioevaara MK, Strandberg TE, Karonen S-L, Ebeling P. Horm Metab Res 2006; 38: 336-340

\section{Erratum}

G. J. Paz-Filho, A. Ayala, K. Esposito, H. K. Erol, T. Delibasi, E. H. Barry, M.-L. Wong, J. Licinio. Effects of leptin on lipid metabolism. Horm Metab Res 2008; 40: 572-574

One of the co-author's name is incorrect. Instead of E. H. Barry, one should read B. E. Hurwitz. His full name is Barry Elliot Hurwitz. 